\title{
Heat consumption scenarios in the rural residential sector: the potential of heat pump-based demand-side management for sustainable heating
}

\author{
José Campos ${ }^{1 *} \mathbb{1}$, Csaba Csontos $^{1}$, Ádám Harmat², Gábor Csüllög ${ }^{1}$ and Béla Munkácsy ${ }^{1}$
}

\begin{abstract}
Background: Poor air quality and inadequate domestic heating sources are tightly connected problems in the Eastern-European countryside. There are a few alternatives to comprehensively solve these problems with an emphasis on economic and environmental sustainability. In this paper, individual heat pumps and energy efficiency measures are analyzed in four scenarios to investigate their role for cleaner and sufficient heating in rural settings. From a high-level perspective, this paper assesses the potential for electricity demand flexibility based on the use of individual heat pumps equipped with hot water storage.
\end{abstract}

Methods: In a first step, the current annual residential heating energy consumption of a rural area in Hungary is estimated with a bottom-up model using data from field surveys and official datasets. In a second step, four scenarios estimate the future heating energy consumption considering demographic trends and the average number of building retrofits (thermal insulation) performed yearly in the region.

Results: The reference scenario is a 20-year projection of heating energy consumption with modest retrofit actions which resulted in small energy savings. Alternative scenarios based on more effective retrofit actions reaching higher rates of the building stock would result in a 23-69\% reduction in final energy consumption. Phasing out lignite from the heating energy mix would reduce particulate matter emissions. Each well-insulated dwelling with a heat pumpbased system and hot water storage tank could provide theoretical flexibility of approximately $3.4 \mathrm{kWh}$ per $24 \mathrm{~h}$.

Conclusions: The current energy retrofit practices are not sufficient to solve the challenges faced in this area. Demand-side management policies based on the widespread use of individual heat pumps are an alternative to promote access to cleaner residential heating. An additional benefit is the potential for flexibility in electricity demand. Thus, this paper calls for an integration of energy retrofit with efficient heating (including hot water storage tank) to achieve results that further contribute to a future of sustainable energy.

Keywords: Demand-side management, Heat pump, Hot water storage tank, Energy retrofit, Scenario development, Demand flexibility, Energy planning

*Correspondence: camposfilhojose@gmail.com; zeca@caesar.elte.hu ${ }^{1}$ Department of Environmental and Landscape Geography, Eötvös Loránd University, Pázmány Péter sétány 1/C, 1117 Budapest, Hungary

Full list of author information is available at the end of the article

\section{Background}

Critical air quality and inadequate domestic heating habits are two tightly connected problems in the Eastern-European countryside [1]. In Hungary, BorsodAbaúj-Zemplén County is one of the most affected areas, where the concentration of particulate matter $(\mathrm{PM})$ often original author(s) and the source, provide a link to the Creative Commons licence, and indicate if changes were made. The images or other third party material in this article are included in the article's Creative Commons licence, unless indicated otherwise in a credit line to the material. If material is not included in the article's Creative Commons licence and your intended use is not permitted by statutory regulation or exceeds the permitted use, you will need to obtain permission directly from the copyright holder. To view a copy of this licence, visit http://creativecommons.org/licenses/by/4.0/. The Creative Commons Public Domain Dedication waiver (http://creativeco mmons.org/publicdomain/zero/1.0/) applies to the data made available in this article, unless otherwise stated in a credit line to the data. 
exceeds the health threshold [2]. In the center of this problem is energy poverty, a complex issue of energy affordability and access to modern and cleaner energy services [3].

Natural gas is the most common source for residential heating in Hungary. Approximately $90 \%$ of the natural gas consumed is imported, placing the country in a dependent position [4]. Natural gas is also the main source of most district heating systems in the country [5]. In rural areas, where currently no district heating systems are operating in the country, firewood is also a common source. Lignite is relatively cheap, particularly in the northern part of the country, and is often used despite its harmful health effects [6].

There are a few possible solutions for improving air quality, with an emphasis on economic and environmental sustainability: energy efficiency and sufficiency measures, district heating, state-of-the-art biomass technologies, and individual heat pumps (HPs) $[7,8]$.

A renewable-based district heating network could provide residential heating and remediate air quality deterioration; however, its development relies on a relatively high initial cost [9]. Moreover, district heating developments are not feasible in some rural areas. Investigating 91\% of the total heat demand in the EU28, Möller et al. estimated that $41 \%$ of all heat demand is contained in areas where district heating is not feasible [7].

The "Heat Roadmap Europe" project suggests that individual HPs can be a solution for low-carbon residential heating in rural circumstances [10]. In residential settings, air-source HPs are the most deployable type, as they are comparable in size to other domestic appliances. Moreover, there is no emission of local air pollutants since the system utilizes ambient heat and electricity to provide useful heat.

In light of the above, this paper focuses on individual HPs, due to the efficiency and controllability of the technology, in combination with the energy retrofit of typical dwellings of a rural area. The purpose is to quantify the effects of demand-side management (DSM) strategies on heating energy consumption, local PM emissions, and, from a high-level perspective, the potential for overall electricity demand flexibility (defined in the next section) based on the use of individual HPs equipped with hot water storage tanks.

Firstly, a brief review of DSM is presented ("Theoretical background"), followed by a description of the data sources and assumptions of the model ("Materials and methods" section). The "Results and discussion" section details a variety of topics; from the findings of the field surveys to projections of future energy consumption. The "Conclusion" section highlights the main findings and recommendations of the study.

\section{Theoretical background}

DSM refers to strategies or set of techniques to achieve greater efficiency and/or to affect the consumer's timing of energy use, most frequently, electricity use [11, 12]. Papaefthymiou et al. (2018) [13] describe the potential for DSM in terms of (a) energy efficiency, (b) large-scale demand-side flexibility, and (c) small-scale demand-side flexibility. (a) comprehends all end-users and has an added value as it reduces total demand and the system's overall need for flexibility; (b) comprehends the industrial potential and can be more easily accessed since the consumer's behavior is typically well known [14]; and (c) comprehends smaller commercial and household consumers and has received increasing interest as it can be a source of flexibility at a low cost with the roll-out of cheaper information and communications technologies (ICT) [15]. Several DSM practices make use of load flexibility; "the ability to adjust electricity demand rapidly as requested to match electricity supply" [16]. This mechanism provides several services to the electricity grid, and are particularly relevant in systems with high penetration of renewable energy sources [17]. Other common applications of DSM policies are:

- modification of peak load consumption [18];

- reduction of dependency on electricity and fuel import [19];

- reduction of the required peak capacity at the national level [20];

- changes in the load profile resulting in load distribution throughout the day [21];

- improvements in the management, planning, and operation of the power grid [20, 22];

- integration of intermittent renewable energy technologies $[17,23,24]$.

Even though preferential electricity tariffs enable DSM by rewarding consumers with financial incentives for peak load shifting [25], social acceptance is either a barrier or a field of opportunities for DSM practices. The consequences of changes in internal comfort are typically the main customer concern. According to surveys conducted after pilot demand response (DR) programs [26], customers have shown satisfaction mainly towards the personal economic benefit and secondly for the chance to reduce electricity consumption. Time-based tariffs could result in benefits from the homeowner's perspective [27]. However, savings may not be significant due to the particular demand profile and local prices [12]. Energy storage can be a solution to match the demand profile and favorable time-based tariffs through cost-effective charging, mainly if an efficient system supplies the storage [28]. 
A heat pump equipped with thermal energy storage (TES), i.e., short-term hot water storage, can be the key component of such heating systems. The overall increase of air-source HP's coefficient of performance (COP), or its more practical seasonal version (SCOP), has made this a viable option also in economic aspects [29]. The COP characterizes the performance of the heat pump as the "ratio of heat exchanged with the indoor environment and the mechanical work supplied to the machine" [30]. The SCOP represents how effective the heat pump is on an annual basis facilitating the comparison between heat pumps and giving a more realistic picture of the efficiency. Formally, the SCOP is "the ratio between the useful energy supplied during the whole season and the energy that has to be provided to the heat pump to obtain this useful energy" [30]. Systems with SCOP as high as 6.0 are currently available in the European market [31].

In the literature, several authors evaluated hot water storage volumes between 1 and $2 \mathrm{~m}^{3}$ for load flexibility and electricity demand response in residential settings [32-34]. Hong et al. [34] looked at the perspectives of manipulating the HP operating times in a detached house. The authors concluded that limited time shifts between 1 and $2 \mathrm{~h}$ are possible even respecting two internal comfort constraints (operative temperatures, which is a measure of human thermal comfort, and hot water supply temperature) in the case of a building insulated to typical levels in the UK [34]. Higher operational flexibility is attainable by combining improved insulation and additional $0.5 \mathrm{~m}^{3}$ storage to the average housing stock, meaning operating time-shifting of 5-6 h [34]. Schuetz et al. [35] argue that increasing the storage size guarantees the off-time of the HP and consequently the flexibility. A storage tank of $1 \mathrm{~m}^{3}$ could even raise the average off-time of the HP by a factor of 20 in comparison to a system without storage [35].

At a global level, the demand-side flexibility potential could reach 185 GW by 2040 [36], and the contribution of residential consumers is a part of it. Based on this figure and aiming at future low-carbon energy systems, several studies have focused on estimating either the theoretical [14] or practical potential for changes in electricity consumption patterns in the regional and national scales $[26,37]$.

The development of long-term scenarios [38, 39] and integrated planning (considering technologies and available resources) are universal tools for strategic decisionmaking involving the energy sector, particularly in rural areas [40]. Beyond spatial planning, Ramirez Camargo and Stoeglehner [41] suggest that spatiotemporal analyses can be applied to estimate energy demand and improve the integration of renewable energy sources [41].
The integrated approach is also the choice in the present study as this paper focuses on energy savings and the role of consumers in the framework of the energy system.

\section{Materials and methods}

The shortage of data on residential heating energy consumption is an obstacle for modeling the sector, particularly in areas that use various energy sources. This study overcomes this obstacle by carrying field surveys and consulting official datasets (when available).

In the field surveys, a standard questionnaire was completed for 1354 households in the region. This work lasted 5 years, with 10 to 15 interviewers on the field on each occasion. Altogether 50-60 people were involved in the interviewing process. The section "Heat demand estimation" describes the content of the surveys.

The official datasets were obtained from the Hungarian Central Statistical Office (KSH) and the Hungarian Energy and Public Utility Regulatory Authority (MEKH).

The Low Emissions Analysis Platform (LEAP) platform [42] is used to model the current heating energy demand and project future demand in four energy retrofit scenarios of the residential stock.

The following subsections describe the characteristics of the area, the variables in the calculations, and the assumptions of the scenarios.

\section{Socio-geographical characteristics of the area}

The Bükkalja region is located in the north-eastern part of Hungary consisting of 20 settlements $\left(564 \mathrm{~km}^{2}\right), 13,014$ houses, and approximately 36,000 inhabitants. The GDP/ capita of the region is $60-70 \%$ of the national average, making this one of the most deprived in the country. The unemployment rate is $42 \%$ higher than the national average, and the average net income is in the lower quartile [43]. The focus on this particular region is due to its need for access to sustainable heating and because of previous community efforts in this aspect.

In 2015, more than 40 settlements in the county were part of a LEADER (a bottom-up rural development initiative) focused on sustainable energy solutions. The main goal was to act towards energy independence, with the motto "One village-one MW". Several renewable energy projects existed within this initiative, most of them being relatively small PV installations, but other bigger independent projects (solar PV and biogas plants) were also created.

Dependence on external energy sources is an issue both in this region and on the national level. Almost all settlements have access to natural gas (which is imported from Russia), with only one exception, Répáshuta, located in the forests of the Bükk mountain. Firewood and lignite are also sources for domestic 
heating in the region. Firewood is partly extracted from the local forest and lignite is mined in the southern part of the area (Fig. 1).

Detached family houses aged between 50 and 100 years are the predominant building type in the area. Most of the housing stock ranks low in energy efficiency standards. It is also common to find residents appealing to the last resort to heat their houses, meaning waste and even plastic. Therefore, due to significant changes suggested by this and similar research projects, the region can be a model of the benefits of smart, efficient heating in community projects.

\section{Heat demand estimation}

Between 2014 and 2019, the area was investigated with door-to-door surveys that added up to a minimum of $10 \%$ of houses in each of the 15 visited settlements. The results were extrapolated to those houses not visited and validated by interviews with representatives of local authorities. Until this stage of the research project, 1354 households were visited, more than ten mayors, several local decision-makers, and experts were interviewed. The other five settlements in the area were not part of the surveying yet, and data from the closest similar settlements were used for estimating the heat demand. The

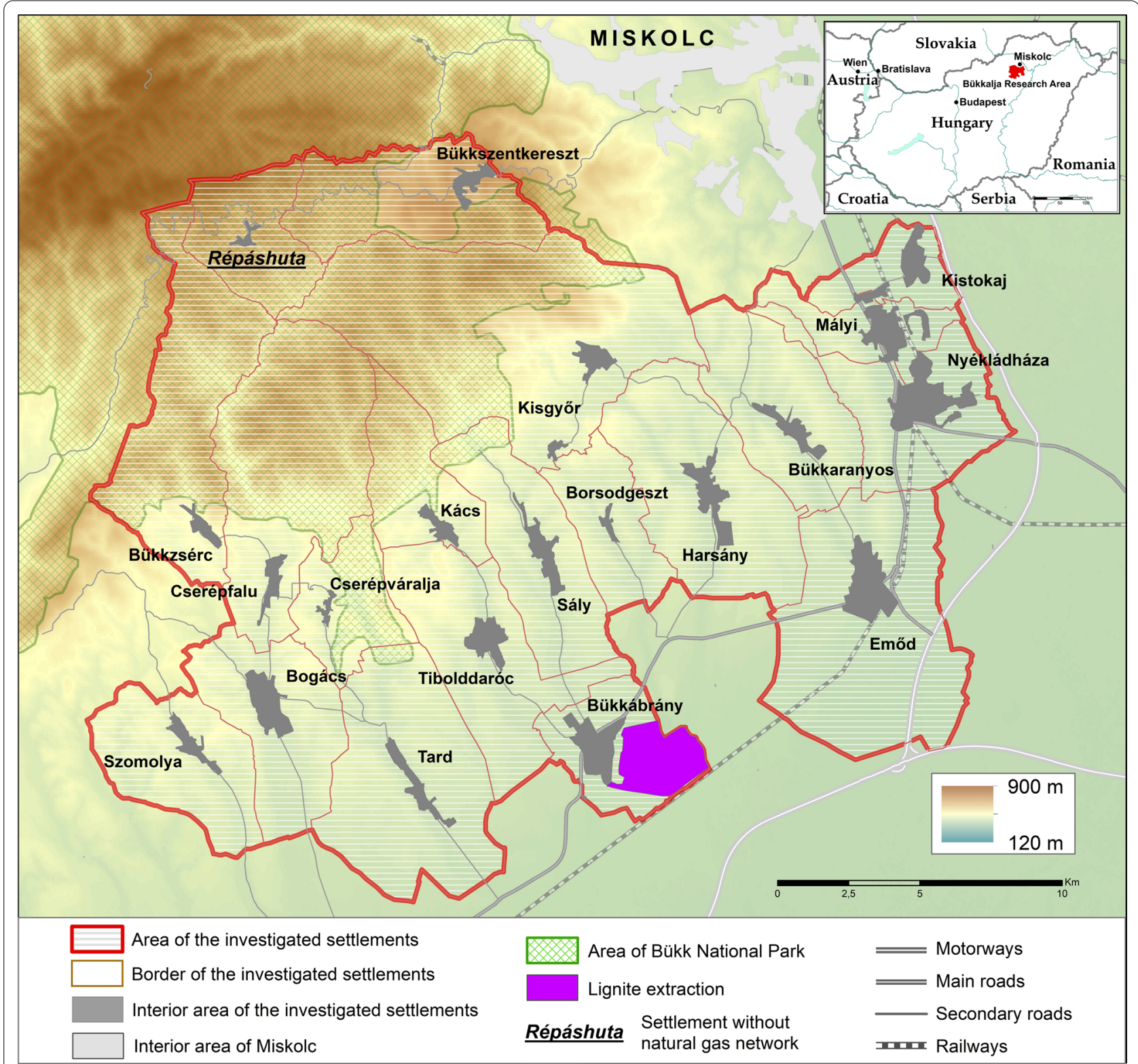

Fig. 1 Location and settlements composing the Bükkalja study area 
same procedure was applied for calculating the average heated area and to define the annual energy demand intensity $\left(\mathrm{kWh} / \mathrm{m}^{2}\right)$.

The field surveys acquired information on (a) "actual energy billing data", including type, quality, and quantity of utilized fuels [44]; and (b) main attributes of residential heat consumption, which include building thermal insulation conditions and stock of heating appliances (the type of boiler, stove or water heater). The average annual heat demand and domestic hot water (DHW) consumption of a single house were calculated by multiplying fuel consumption by the average efficiency of the conversion processes of typical heating devices (Table 1). Efficiency values were adopted based on observations during the field surveys and typical appliances in the Hungarian residential stock reported by Csoknyai et al. [45].

Net energy intensity for space heating and DHW was validated by comparison to data of the Tabula-Episcope project [49]. The project developed a database on the European housing stock and provided scenario calculations for refurbishment and energy-saving perspectives in several countries. The reference data for this paper is the Hungarian single-family houses built between 1945 and 1979.

\section{Technologies considered in the model}

The envisaged retrofit consists of a low-temperature heating system supplied by air-to-water HP, different levels of thermal insulation of the building, airtightness improvements, window glazing, and entrance door replacement [50].

Another crucial element proposed is the hot water storage tank coupled with the air-to-water HP. The HP unit chosen as the reference is an appliance with typical technical features [31]. In this specific unit, the maximum water temperature for space heating is $55^{\circ} \mathrm{C}$, resulting in a SCOP of 3.47. A small tank (185 l) is integrated into the unit supplying DHW at $65^{\circ} \mathrm{C}$ with SCOP of 3.3. The system's SCOP adopted in the calculations was 3.4. Sensible heat storage consisting of a water tank with a capacity of $1 \mathrm{~m}^{3}$ was considered based on the design presented by Arteconi et al. [33].

Table 1 Conversion and efficiency factors in the light of local capabilities. Source: [46-48]

\begin{tabular}{lllll}
\hline Fuel type & Values & Units & Appliance & Efficiency \\
\hline $\begin{array}{l}\text { Firewood (mois- } \\
\text { ture content }\end{array}$ & 2.42 & $\mathrm{MWh} / \mathrm{m}^{3}$ & Wood burning stove & 0.55 \\
$45 \%$ ) & & & & \\
Natural gas & 9.60 & $\mathrm{kWh} / \mathrm{m}^{3}$ & Boiler & 0.75 \\
Lignite & 2.44 & $\mathrm{kWh} / \mathrm{kg}$ & Multi-fuel stove & 0.45 \\
Electricity & 1 & $\mathrm{kWh}$ & Water heater & 0.85 \\
\hline
\end{tabular}

The potential flexibility in the present study refers to the possibility to decrease electricity demand by shifting consumption to an earlier or later time within $24 \mathrm{~h}$. The exploitation of aggregated demand flexibility of consumers [51] could reduce winter peak load (typically between 16:00 and 19:00 in Hungary [52]). Demand aggregated from small end-users could prospectively be offered in the wholesale electricity market [53] or used to match generation from renewable sources such as solar PV and wind $[25,55]$.

In practice, approximately $11.5 \mathrm{kWh}$ of heat could be stored if an envisaged well-insulated dwelling would be equipped with a 1000-L hot water storage tank (assuming a $10{ }^{\circ} \mathrm{C}$ difference in inlet $\left[45^{\circ} \mathrm{C}\right]$ and outlet $\left[55^{\circ} \mathrm{C}\right]$ temperature of the water tank) [55]. As a simple example, assuming electric water heaters with an efficiency of $100 \%, 88$ dwellings would represent $1 \mathrm{MWh}$ of electricity conversion and storage [37]. Applying the same parameters but considering the potential for electricity demand shifting, 500 dwellings each equipped with a $2-\mathrm{kW}$ electric heating system would represent $1 \mathrm{MW}$ of flexibility.

Annual residential heat demand values were divided by the system's SCOP to estimate the electricity consumption in this period. In Hungary, space heating is required for approximately 180 days per year. Therefore, the daily average was obtained by dividing the annual heat demand by 180 days.

Each envisaged house could theoretically provide maximum flexibility (Eq. 1) equivalent to the consumption of the system operating with the given SCOP value [30]. This capacity also means the possibility to move demand from one hour to the next, or for shorter intervals, without compromising the thermal comfort of the residents, which is guaranteed by the thermal storage within the limit defined in Eq. 3.

$$
L_{\text {shift }, \mathrm{H}}=i_{h p} \times 1 / \eta_{p}
$$

In Eq. $1, i_{\mathrm{hp}}$ is the capacity of the system defined in the scenario description ranging from 4 to $5 \mathrm{~kW}$ and $\eta_{p}$ is the seasonal coefficient of performance. Based on the calculations in [37], the aggregated potential of the study area ( $\left.L_{\text {shift,A }}\right)$ is calculated by multiplying $L_{\text {shift,H }}$ by the number of houses equipped with HPs.

The storage capacity was adopted considering the limitations of existing buildings, meaning that tanks larger than $1 \mathrm{~m}^{3}$ may be too large to be installed. Based on the air-to-water HP and water tank setting investigated by Renaldi et al. [55], Eq. 2 results in the storage capacity (in $\mathrm{kWh}$ ). In this equation, $v$ is the volume $\left(1 \mathrm{~m}^{3}\right), \rho$ is the water density $\left(988.04 \mathrm{~kg} / \mathrm{m}^{3}\right), c_{p}$ is the specific heat $(4.18 \mathrm{~kJ} / \mathrm{kg} / \mathrm{K})$, and $\Delta T$ is the temperature difference (10 K): 


$$
Q_{\text {storage }}=v \times \rho \times c_{p} \times \Delta T / 3600 .
$$

The electricity required to heat the water stored in the tank is the limit per shifting cycle or for every $24 \mathrm{~h}$ (Eq. 3) [55]. This restriction ensures indoor thermal comfort during power shifting periods [35], meaning that the hot water stored in the tank can supply the household during HP downtime. This assumption is conservative because the building insulation contributes to maintaining indoor comfort.

$$
e_{\text {cycle }}=Q_{\text {storage }} \times \frac{1}{\eta_{p}} .
$$

This paper did not take into account dynamic effects in the calculations. Nevertheless, based on the literature, some aspects of dynamic load control required to utilize the potential flexibility are described in the discussion section.

\section{Description of the scenarios}

The scenarios comprehend the period from 2020 to 2040 and have demographic trends as a central element. The number of houses $(13,014)$ and the population changes in the last 20 years were considered as an ongoing trend showing a $10 \%$ decline $[56,57]$. The pattern was adopted in all scenarios until 2040, meaning another $10 \%$ average decrease. More specifically, the population movement appears in an overall 10\% decrease in the number of occupied houses. Because the population movement trend differs within the area, each settlement was treated individually. At one extreme, in Kács, the population is expected to decrease by $34 \%$. At the opposite end, in Kistokaj, this number is expected to increase by $16 \%$. These are explained by the impact of population aging and movement from the countryside to bigger cities and more prosperous suburban settlements observed in the last two decades.

The scenarios were designed around two elements: fuel switching and energy retrofit of the housing stock. Fuel switching was implemented with heat pumps first replacing lignite-based systems due to the high local air-polluting impact of lignite. In those settlements that do not use lignite in large amounts, natural gas was the second fuel replaced. This fuel was among the priorities because it is mostly imported. Firewood was the third source replaced after lignite and natural gas. Firewood is among the priorities because its consumption is currently beyond the sustainability limit of the local forest [58].

Considering that it is not reasonable to modernize the heating system if the building does not go under insulation improvements, the alternative scenarios are described in terms of the effectiveness of the renovation and the annual rate of housing stock renovations (Table 2).

Scenario business-as-usual (BAU) Considers the socalled "Standard Renovation" [59]. This renovation level consists of the insulation of the building envelope (e.g., façade), and a partial replacement of windows and entrance doors. This renovation package results in a $50 \%$ reduction in net heat demand [49]. Based on interviews with local decision-makers, $0.5 \%$ of the housing stock is improved with this level of renovation per year.

Scenario standard energy efficiency (SEE) Also considers the "Standard Renovation" level, but the annual rate of renovations is increased to $1.25 \%$ of the housing stock [50]. As a theoretical solution, modernization of the heating system is considered solely with air-to-water $\mathrm{HP}$ (heating power of $5 \mathrm{~kW}$ ), hot water storage tank, and low-temperature heating.

Scenario advanced energy efficiency (AEE) Considers the "Advanced Renovation" concept, which would result in $66 \%[50,60]$ reduction in net heat demand. Air-towater $\mathrm{HP}$ (heating power of $4 \mathrm{~kW}$ ), hot water storage tank, and low-temperature heating are considered at an increased renovation rate of $2.5 \%$ of the housing stock per year.

Scenario deep energy efficiency (DEE) This is a more ambitious scenario based on a whole-building evaluation and insulation improvements, known as the Nearly ZeroEnergy Building (NZEB) concept. Modernization of the

\begin{tabular}{|c|c|c|c|}
\hline Scenario & Description & $\begin{array}{l}\text { Renovation rate (\% } \\
\text { of the stock/year) }\end{array}$ & $\begin{array}{l}\text { Energy } \\
\text { savings (\% } \\
\text { reduction) }\end{array}$ \\
\hline BAU & Current (moderate) energy performance improvements & 0.50 & 50 \\
\hline SEE & $\begin{array}{l}\text { Current (moderate) energy performance improvements, low-temperature heating system, air-to- } \\
\text { water heat pump, hot water storage tank }\end{array}$ & 1.25 & 50 \\
\hline AEE & $\begin{array}{l}\text { Advanced energy retrofit, low-temperature heating system, air-to-water heat pump, hot water stor- } \\
\text { age tank }\end{array}$ & 2.50 & 66 \\
\hline DEE & $\begin{array}{l}\text { Deep energy retrofit, low-temperature heating system, air-to-water heat pump, hot water storage } \\
\text { tank }\end{array}$ & 3.75 & 75 \\
\hline
\end{tabular}

Table 2 Summary of scenarios. Source: $[49,50,59,60]$ 
heating system is considered with air-to-water HP (heating power of $4 \mathrm{~kW})$, hot water storage tank, and low-temperature heating system. The scenario considers a $75 \%$ reduction in the current net heat demand of an average building $[50,60]$ at a rate of $3.75 \%$ of the housing stock per year.

Fuel switching and effects of energy retrofit were managed using LEAP (The Low Emissions Analysis Platform [42]), and scenarios were created for each settlement in the study region. The platform is a scenario-based model that allows users to define detailed characteristics of the energy system (e.g., supply and demand) in a bottom-up approach. Energy demand reports and environmental reports are some of the indicators available to the user.

The platform is mentioned in analyses of the transportation sector [61] and scenario development for environmental and energy planning in countries with limited data [62]. Concerning the residential sector, LEAP has been used for comparing energy consumption and $\mathrm{CO}_{2}$ emissions of efficiency actions [63]. Subramanyam et al. [64] modeled the residential heating sector and concluded that efficient appliances could significantly contribute to mitigating GHG emissions.

LEAP was the choice for the present study because of the possibility to define several end-use fuels and technologies and link energy demand to demographic trends. Moreover, it is possible to define which fuels are phased out. $\mathrm{CO}_{2}$ and $\mathrm{PM}_{10}$ emissions were also estimated using LEAP.

\section{Emissions}

$\mathrm{CO}_{2}$ emissions were estimated to compare the environmental impacts of different energy carriers. Local $\mathrm{PM}_{10}$ emissions of the residential heating were calculated to compare the air-polluting effects of different energy carriers. Only end-user-related $\mathrm{CO}_{2}$ and $\mathrm{PM}_{10}$ emissions were considered in the estimation. For such, the characteristics of residential combustion of natural gas [65] and lignite [66] and the carbon intensity of the electricity consumed in Hungary were considered [67]. Firewood was assumed to be a carbon-neutral source and transportation emissions were not estimated for firewood or lignite due to the lack of data on the required scale.

Lignite and firewood are the main sources of $\mathrm{PM}_{10}$ emissions related to heating in the study area (Table 3). $\mathrm{PM}_{10}$ emissions caused by electricity production are not accounted for since the area is connected to the national grid. Natural gas does not contribute significantly due to its low sulfur content [65]. The average emission factor for lignite was based on [68], and emissions for firewood are based on the analysis carried by Kistler et al. [69] for typical types of wood of Central Europe. An upper and
Table 3 Average carbon intensity and $\mathrm{PM}_{10}$ emissions of the typical energy sources in the study area. Source: [65-69]

\begin{tabular}{lllll}
\hline & Electricity & Natural gas & Lignite & Firewood \\
\hline $\mathrm{CO}_{2}(\mathrm{~kg} / \mathrm{kWh})^{*}$ & 0.369 & 0.185 & 1.334 & - \\
Local PM $_{10}(\mathrm{~g} / \mathrm{kWh})^{* *}$ & - & 0.001 & 1.400 & $0.251-0.504$ \\
\hline
\end{tabular}

${ }^{*} \mathrm{CO}_{2}$ emissions associated with transportation are not included

**PM ${ }_{10}$ emissions associated with electricity generation are not included

lower range was defined for firewood emissions due to significant variations of wood type and heating devices.

\section{Payback estimation}

The financial evaluation was expressed in terms of the payback time of the retrofit scenarios. The simple payback time approach is common to investigate the potential of retrofitting existing buildings [70].

Unit costs of the retrofit actions make use of data reported by Harvey [50]. The average cost of the energy source has a direct impact on the payback time. Therefore, two payback period scenarios (both without incentives) demonstrate the sensitivity to natural gas prices. Payback period "A" considered the average European natural gas cost of $0.0632 € / \mathrm{kWh}$ and Payback period "B" considered the average Hungarian natural gas cost of $0.0346 € / \mathrm{kWh}$ [71]. Expenses related to replacing the heating system were based on $[72,73]$.

\section{Results and discussion}

This section is structured into four parts according to the results treated (Fig. 2). Part A concerns the estimated net heat demand of an average dwelling and how it compares to the literature [49]. The total net heat demand of the region and projections for 2040 are also discussed in the first part. Part B1 concerns the final energy to cover the net heat demand and Part B2 deals with the associated emissions. The four scenarios are graphically compared in terms of fuel type, final energy consumption, and emissions of $\mathrm{CO}_{2}$ and $\mathrm{PM}_{10}$. Part $\mathrm{C}$ briefly examines the economic implications of the retrofit measures (investments and payback period). Part D concerns the electricity consumption in the three alternative scenarios and the aggregated flexibility from HPs coupled with hot water storage tanks. This part also reviews several obstacles in accessing the flexibility of residential consumers.

\section{Part A: net heat demand}

Considering the current state of the building stock, the average annual net heat demand is estimated at 132 $\mathrm{kWh} / \mathrm{m}^{2}$. This value is $12 \%$ lower than the value derived from the Tabula-Episcope project $\left(149.9 \mathrm{kWh} / \mathrm{m}^{2}\right)$ for an average detached house built between 1945 and 1979 


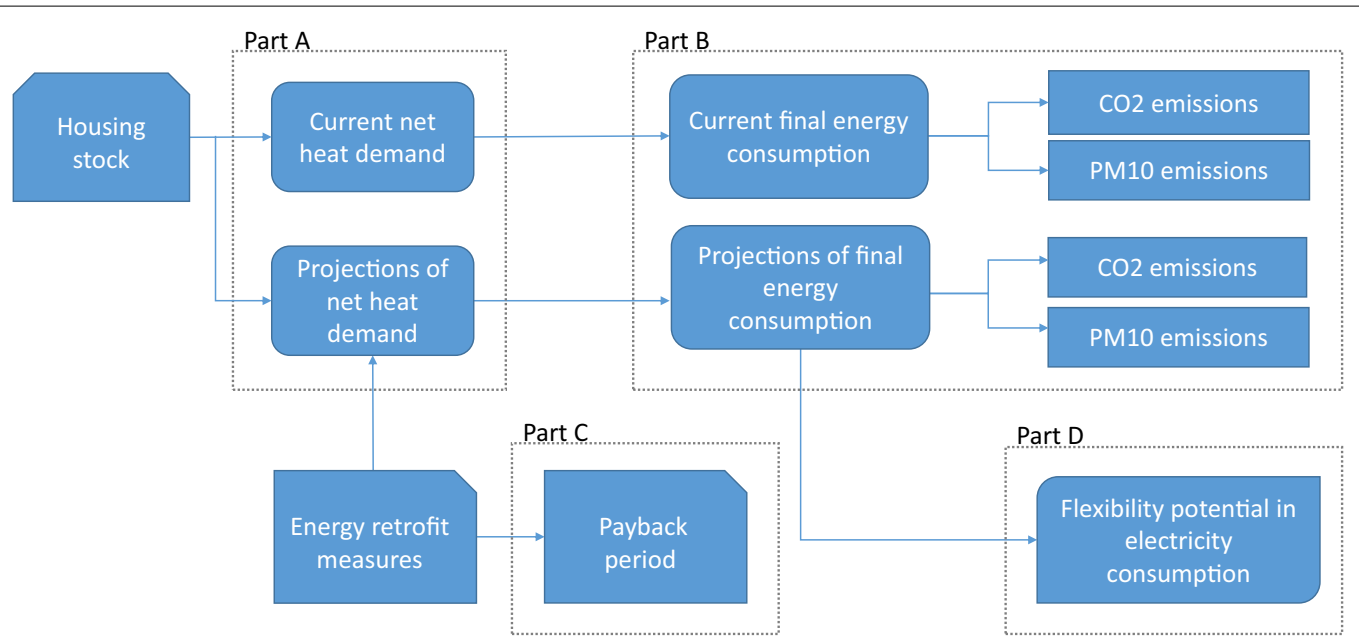

Fig. 2 Overview of the proceedings of the study. Part A, B, C, and D refer to the topics in the "Results and discussion" section

[49]. This type of residence described in the Tabula-Episcope project corresponds to most of the houses in the study area. Since some buildings are newer and have better energy performance, the $12 \%$ difference was considered satisfactory.

The total net heat demand of the area is estimated at 159.1 GWh/year. The BAU scenario was the reference to estimate the change in energy consumption in the study period considering the population movement and current retrofit rate. Scenario BAU projects the total net heat demand of the area at $138.8 \mathrm{GWh}$ in 2040. Scenarios SEE, AEE, and DEE were compared to the BAU 2040, revealing a possible reduction in the order of $10 \%, 30 \%$, and $50 \%$, respectively. Comparing scenarios SEE, AEE, and DEE to the current state, the scenarios would represent in 2040 a reduction in the order of $20 \%, 40 \%$, and $60 \%$, respectively.

Since one specific SCOP value was used as a reference, the results are sensitive to HPs currently used. However, more efficient technologies are and will likely be available on the market before the end of the study period.

\section{Part B1: final energy consumption}

Natural gas, firewood, and lignite are the most common sources for residential heating in the region. Electricity is often used to provide DHW in the region, but not for space heating. Lignite is the dominant source in settlements close to the mining site due to lower prices in comparison to other fuels. Fuel prices and high investment costs of more efficient systems are the main factors influencing the current heating energy mix of the region (Fig. 3).

The final energy consumption for heating and DHW of the 13,014 dwellings composing the study area is estimated at $240 \mathrm{GWh}$ per year. Each dwelling consumes on average 18.4 MWh/year. The national average calculated for the period 2015-2018 is $14.6 \mathrm{MWh}$ /year [74]. The higher consumption in the study area is explained by the inadequate conditions of the housing stock.

An average dwelling has a heated floor area of approximately $90 \mathrm{~m}^{2}$ and annual final energy consumption of $203 \mathrm{kWh} / \mathrm{m}^{2}$ (red line, Fig. 4). Larger positive anomalies were observed in two settlements. According to the survey, households in Bükkábrány and Kács have $23.8 \%$ and $17.6 \%$ higher final energy consumption than the average in the study area, respectively.

The projected final energy consumption in 2040 is estimated at $209 \mathrm{GWh}$, a 13\% decrease from the current average annual value. Fuels currently used represent the majority of sources in the scenario BAU. The alternative scenarios consider that electricity and ambient heat replace these energy sources prioritizing the elimination of lignite.

Ambient heat is considered a practically "infinite" resource, as thermal energy is utilized from outdoor air, even at relatively low temperatures $\left(-15^{\circ} \mathrm{C}\right)$. Since electricity-based space heating is not common in the region, the overall electricity consumption would increase if HPs are introduced with rates indicated in any of the scenarios (Fig. 5). The increase in electricity consumption in scenario DEE is small due to higher efficiency measures.

A $23 \%$ reduction in final energy consumption is observed when comparing scenario SEE to BAU by the end of the study period (2040). This value includes ambient heat utilization. Lignite cannot be phased out with the renovation rate described in scenario SEE. When scenarios AEE and DEE are compared to BAU, the reduction is in the order of $46 \%$ and $69 \%$, respectively. Lignite could be phased out with actions described in scenarios AEE and DEE. 


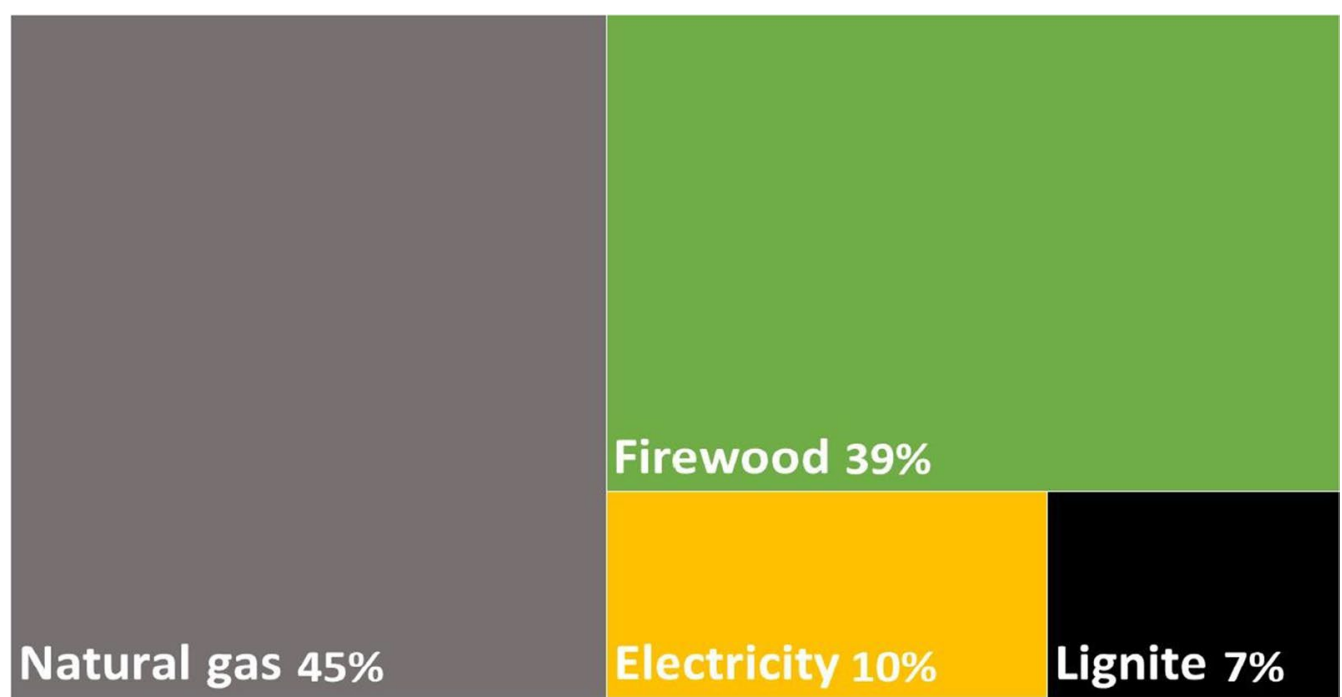

Fig. 3 The current residential end-energy mix for heating in the study area. Source: own surveys

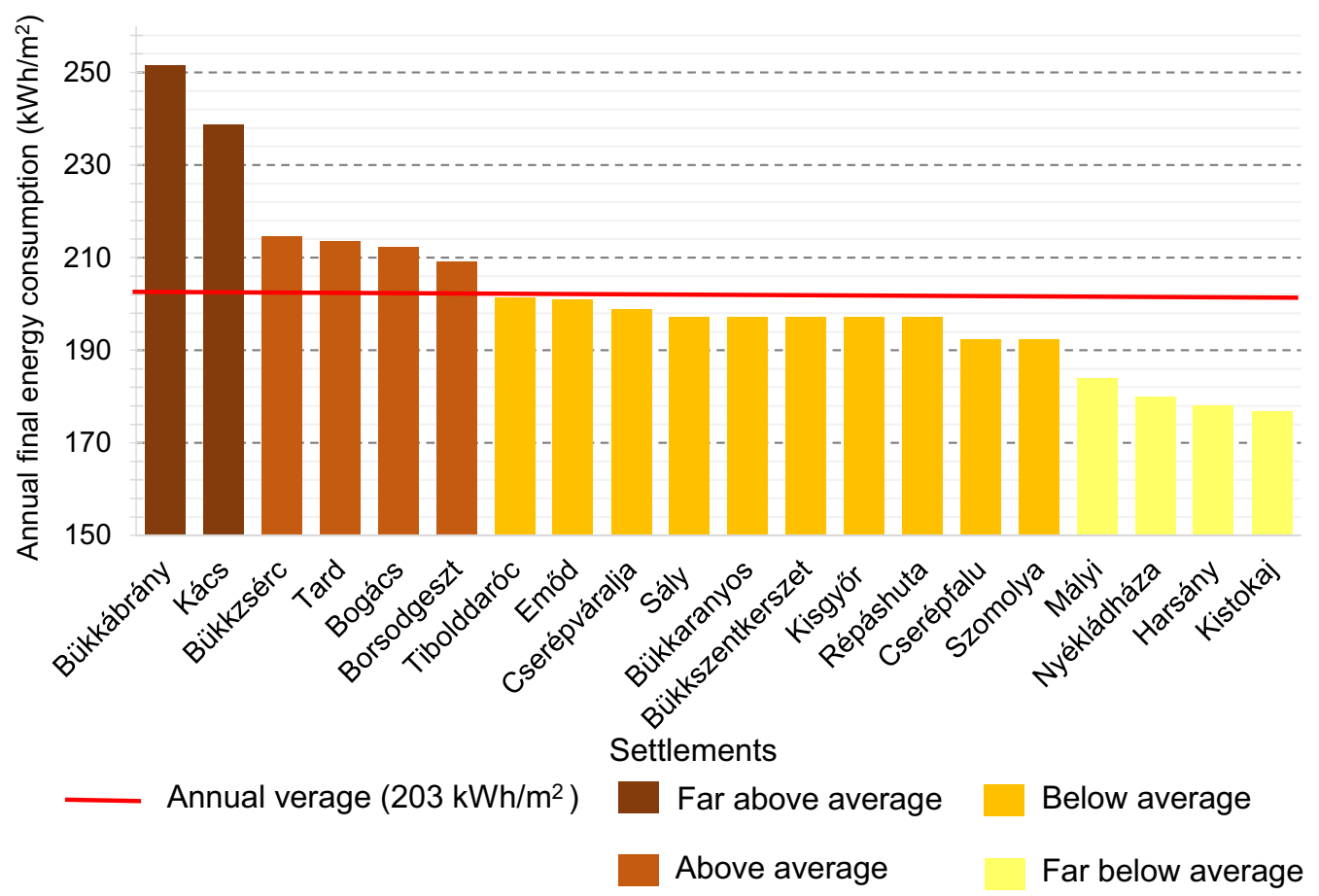

Fig. 4 Annual final energy consumption of households for heating and hot water in each settlement composing the study area. The red line at 203 $\mathrm{kWh} / \mathrm{m}^{2}$ is the average of the 20 settlements. Source: own surveys 


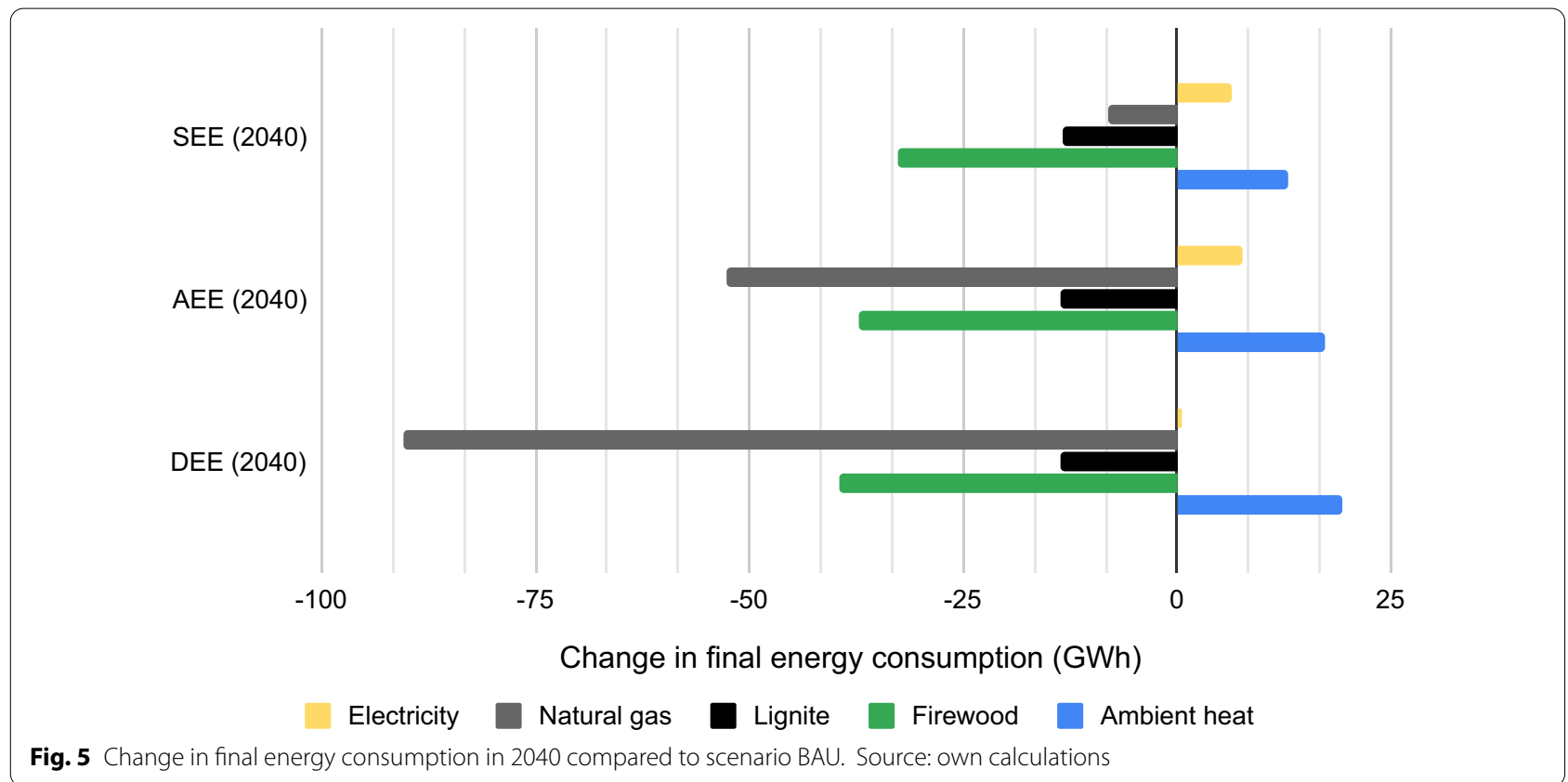

Natural gas consumption could be reduced by half with the renovation rate described in scenarios AEE and almost phased out with strategies described in scenario DEE.

\section{Part B2: emissions}

It is estimated that between 46 and 70 tonnes of heating-related $\mathrm{PM}_{10}$ are emitted every year (current
state-Fig. 6). Emissions were projected at 40-60 tonnes in 2040 (scenario BAU). Scenarios SEE, AEE, and DEE result in $70-75 \%$ fewer emissions in comparison to the current state (Fig. 6). The three alternative scenarios only differ by $5 \%$ because even though firewood and natural gas are also replaced, lignite is almost phased out in scenario SEE.

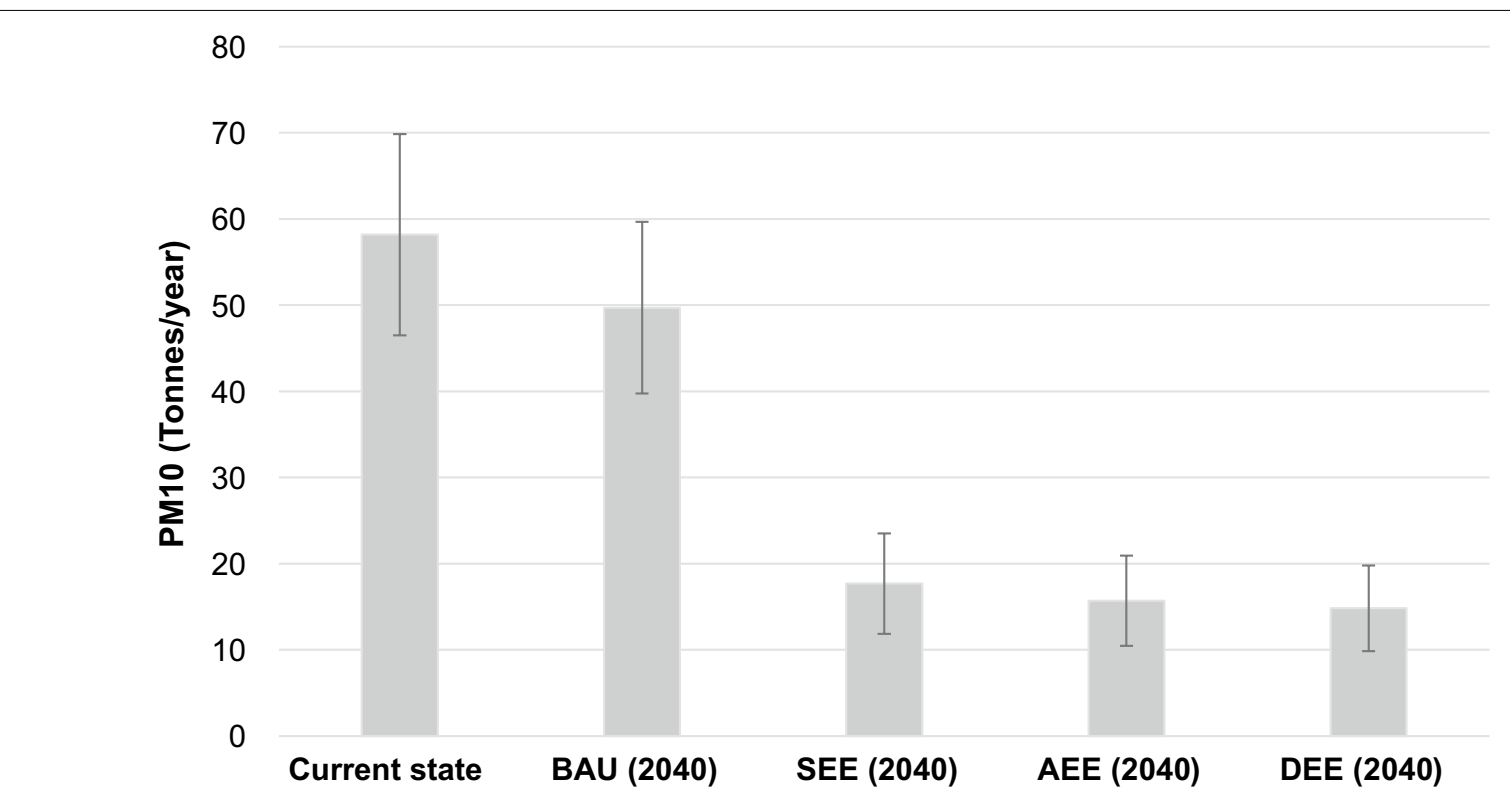

Fig. 6 Total estimated emission of $\mathrm{PM}_{10}$. Error whiskers in terms of upper and lower emission factors for firewood combustion. Source: own calculations 


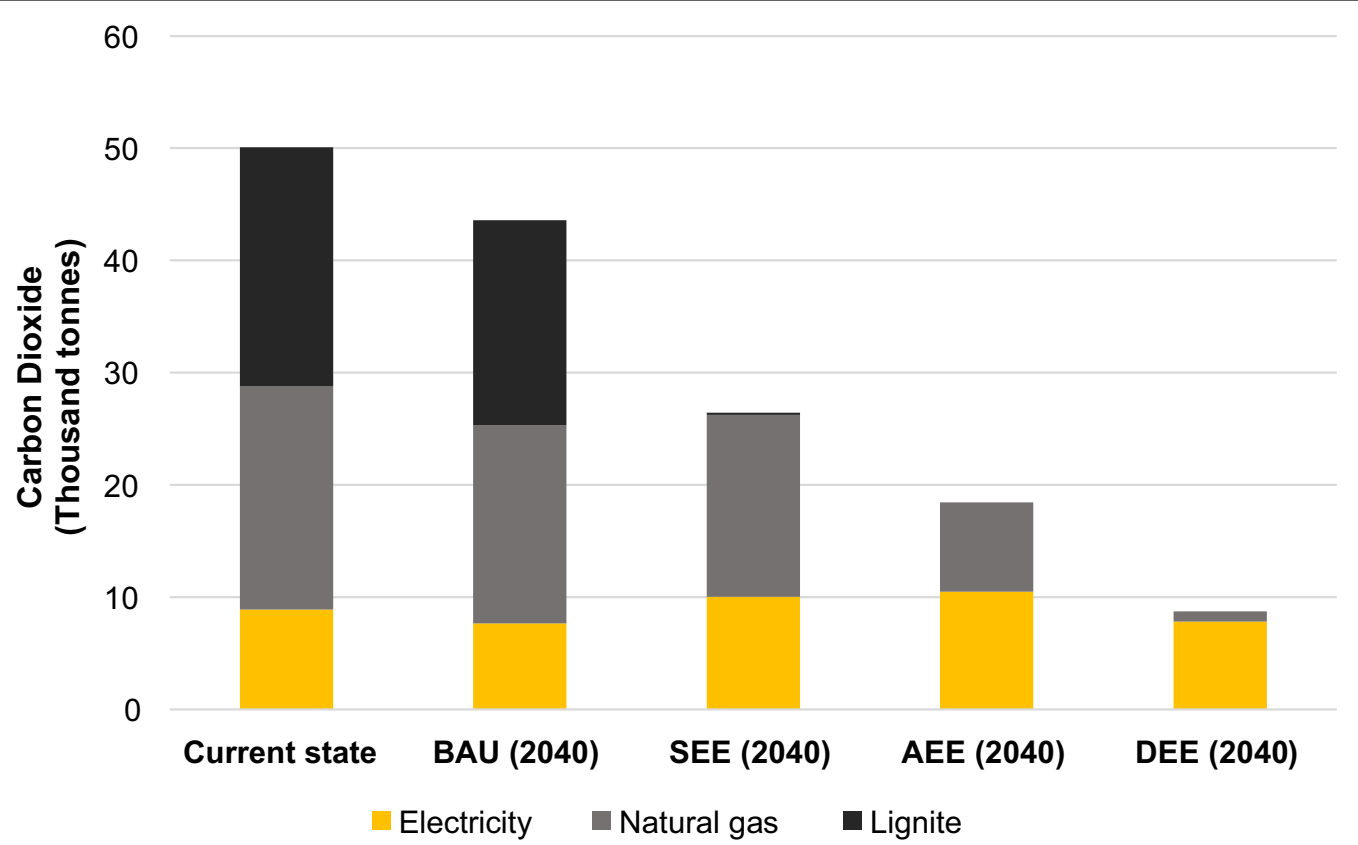

Fig. 7 Annual $\mathrm{CO}_{2}$ emissions by end-use energy source for residential heating. Transportation emissions are not considered in the calculations. Source: own calculations

Burning of domestic waste is another factor contributing to PM emissions; however, emissions from these activities are challenging to estimate due to waste heterogeneity.

$\mathrm{CO}_{2}$ emissions are presented in Fig. 7 for a comparison of different energy carriers. Since fuel switching is only considered with associated energy efficiency measures, the increase in electricity consumption and emissions are not proportional to emissions of fuels phased out. Consuming electricity from the national grid would result in lower emissions than burning lignite or natural gas (in residential settings) to produce the required heat. Please note that this estimation is valid for the current average carbon intensity of the electricity consumed in the country.

\section{Part C: payback period}

The different payback periods among the scenarios are caused by decreasing energy needs as the efficiency measures are increased. Thus, a more extended payback period is needed if lower fuel costs apply. The payback periods can be reduced with financial incentives for building renovation and energy-saving initiatives. Dall'O' et al. [70] suggest that incentives could reduce payback time by $55 \%$.

The results (Table 4) consider one average dwelling in the study area. Other aspects would need consideration, namely, assessment on a building-by-building basis and the effects of renovation on the property value. Even though deep renovation measures result in a more extended payback period, it can be preferred as the

Table 4 Payback period evaluation of retrofit scenarios for one average dwelling in the study area. Source: own calculations and [50, 70-73]

\begin{tabular}{|c|c|c|c|c|c|c|c|c|}
\hline $\begin{array}{l}\text { Retrofit } \\
\text { scenario }\end{array}$ & $\begin{array}{l}\text { Unit costs } \\
\left(€ / \mathrm{m}^{2}\right)\end{array}$ & $\begin{array}{l}\text { Heating } \\
\text { system cost } \\
(€)\end{array}$ & Total costs $(€)$ & $\begin{array}{l}\text { Energy savings } \\
\text { (kWh/year) }\end{array}$ & $\begin{array}{l}\text { Money savings } \\
\text { "A" (€/year) }\end{array}$ & $\begin{array}{l}\text { Payback } \\
\text { period "A" } \\
\text { (years) }\end{array}$ & $\begin{array}{l}\text { Money savings } \\
\text { "B" (€/year) }\end{array}$ & $\begin{array}{l}\text { Payback } \\
\text { period "B" } \\
\text { (years) }\end{array}$ \\
\hline SEE & 100 & 7000 & 16,000 & 14,093 & 891 & 18.0 & 493 & 32.4 \\
\hline AEE & 130 & 7100 & 18,800 & 14,652 & 926 & 20.3 & 513 & 36.7 \\
\hline DEE & 150 & 7100 & 20,600 & 14,967 & 946 & 21.8 & 524 & 39.3 \\
\hline
\end{tabular}

*No financial incentives for building renovation and energy saving are considered in this evaluation 
Table 5 Estimated electricity consumption and potential demand flexibility in 2040. Source: own calculations

\begin{tabular}{|c|c|c|c|c|}
\hline & \multirow[b]{2}{*}{ Scale } & \multicolumn{3}{|c|}{ Scenario } \\
\hline & & SEE & AEE & DEE \\
\hline Retrofit target by 2040 (number of houses) & Study area & 2907 & 5813 & 8720 \\
\hline Share of the total (\%) & Study area & 25 & 50 & 75 \\
\hline Total electricity consumption for heating (MWh/year) & Study area & 5372.2 & 7163.0 & 8058.4 \\
\hline Average electricity consumption for heating ( $\mathrm{kWh} /$ year) & Household & 1848.0 & 1232.2 & 924.1 \\
\hline Theoretical flexibility $L_{\text {shift, }}(\mathrm{kW})$ & Household & 1.5 & 1.2 & 1.2 \\
\hline $\begin{array}{l}\text { Aggregated theoretical flexibility } \\
L_{\text {shift,A }}(M W)\end{array}$ & Study area & 4.3 & 6.8 & 10.2 \\
\hline Total flexibility per $24 \mathrm{~h}$ (kWh electricity) & Household & 3.4 & 3.4 & 3.4 \\
\hline Heat storage capacity (kWh heat) & Household & 11.5 & 11.5 & 11.5 \\
\hline
\end{tabular}

property value will also likely increase [75]. Other economic benefits need to be considered at the policy and planning levels, including, tax revenue and job-creating [76], environmental impacts, and health benefits [77].

\section{Part D: Electricity demand and flexibility}

The estimated electricity consumption of the whole area and one representative dwelling are presented in lines 3 and 4 of Table 5 . Please note that line 3 of Table 5 sums up the consumption of each settlement and is therefore not the same as multiplying one representative dwelling by the number of houses in the area.

Continuous cycles of load shifting were limited by the electricity required to heat water that is stored in the tank. Therefore, considering a 1000-L hot water storage tank as the guarantee of heat supply, the maximum energy that can be shifted continuously without compromising thermal comfort is $3.37 \mathrm{kWh} / \mathrm{dwelling}$. This amount of energy is also the limit for every $24 \mathrm{~h}$. The potential flexibility per dwelling (line 5 of Table 5) refers to HP operation at full capacity during the heating season.

Similarly, the aggregated flexibility (line 6, Table 5) is a theoretical maximum potential that would only be achieved if all HPs move their entire load from a given moment, all at the same time. For load reduction, this potential would not always be available because some HPs may not be operating at this specific moment.

Moreover, electricity demand flexibility is treated as theoretical potential in this paper because, in the case of residential consumers, the patterns of demand vary, and detailed data on the consumer's behavior is needed [27]. The widespread availability of ICT (i.e., smart meters) and financial incentives are crucial for overcoming this obstacle. Nevertheless, Valero et al. [78] highlight that the definition of demand segments and the potential of the customer cluster is an essential step of the process.
At the national level, the latest census recorded 2,585,226 detached houses in Hungary [79]. Considering the survey results and the retrofit target of 8720 dwellings, it is possible to estimate, at least the order of magnitude of the potential at the national level. Extrapolating the research outcomes, theoretically, the maximum of approximately $2281 \mathrm{MWh}$ electricity consumption could be shifted to an earlier or later time provided that $75 \%$ of the detached houses would be equipped with an electrical HP and hot water storage. This amount of electricity is more than the hourly production of the largest power station in the country. Considering the recent average 6000-6600 MW peak electricity demand in the heating season [52], residential HP systems operating with hot water storage could play a significant role in DSM.

A downside of increasing the number of individual HPs is that the peak loads would also increase and likely cause voltage and congestion problems in low-voltage distribution grids [80]. According to Protopapadaki and Saelens [81], voltage stability problems could be critical, particularly in rural networks, and congestion issues can be expected already at HP penetrations of $30 \%$. McKenna et al. [82] indicate that grid reinforcements may be required even at $25 \%$ penetration of HPs in rural settings.

To alleviate the effects on the power system and to cope with the systems' need to rapidly match supply and demand, proper control of the heating system, including the storage tank, is required. The need for automatic control implies that several technical obstacles need to be overcome first: energy management systems (units that react to price or other automated signals) need to be available to all dwellings in the demand response program. Moreover, the residents' willingness to enroll and contribute to the program would be crucial. McKenna and Thomson [83] argue that domestic consumers are changing their "demand response behavior" and extending their practices beyond typical appliances (washing 
machines, dishwashers, heating appliances) to cleaning and cooking practices as long as they see benefits. However, limited financial incentives to consumers is an economic barrier [84]. Another obstacle is the design and regulatory framework of the electricity market, which needs to allow load aggregators to trade demand flexibility [51, 85]. A careful investigation of these obstacles is still needed.

\section{Conclusion}

This paper has analyzed the current residential heating energy consumption of a typical rural area in Hungary. The heating energy consumption and associated $\mathrm{PM}_{10}$ emissions were projected for 2040 in a business-as-usual and three alternative scenarios considering demographic trends and energy retrofit of the residential stock. Due to poor insulation conditions and inadequate heating sources in the area (namely lignite), the current housing stock retrofit rate of $0.5 \%$ per year is not enough to obtain even minimal results in the field of energy sufficiency, let alone in the "climate battle". Increasing the retrofit rate to $2.5 \%$ would reduce the total emissions of local air pollutants but would not significantly reduce annual heating energy consumption. The main suggestion for this particular area is that the retrofit process needs to be accelerated to at least $3.75 \%$ of the residential stock per year. These energy retrofits should include thermal insulation of the building and lignite-based systems should be phased out, preferably being replaced by efficient heat pump systems as suggested by the results described above.

One step further would be to use rooftop solar PVs to supplement the HP. A system of $0.70-0.75 \mathrm{~kW}$ capacity [86], which is only $10 \%$ of the average system $(7.6 \mathrm{~kW})$ equipped in the last quarter of 2018 in Hungary [87], could generate the equivalent annual electricity consumption for heating of an envisaged dwelling ( $925 \mathrm{KWh}$ in scenario DEE). While the addition of a solar PV system would not solve the aforementioned peak demand problems of the distribution grid outright (as PV generation and heat demand fluctuate daily/seasonally), it is recommended to further investigate the addition of solar PV in any building energy retrofit.

Nevertheless, energy poverty is a barrier for retrofit plans in this region, and without external subsidies, it is impossible to reach most households. The price of an airto-water HP system and storage tank altogether, without any additional costs, would be eight times higher than the average monthly salary in the county [88]. Moreover, without external support, the payback period is not particularly attractive. The uptake of HPs would highly depend on incentive tariff systems or investment subsidies, as well as communication campaigns and financial regulation.

With this in mind, the investigated alternative could promote access to cleaner heating in rural areas facing similar challenges. An added benefit is the potential for flexibility in electricity demand, provided that a hot water storage tank is available. While the field of demand flexibility at the residential level is promising, there are still many obstacles in the way of its effective use. The strong integration of energy efficiency measures with consumer participation would be critical for demand response programs and in ensuring a future of sustainable energy.

\section{Abbreviations}

AEE: Scenario advanced energy efficiency; BAU: Business as usual; COP: Coefficient of performance; DEE: Scenario deep energy efficiency; DHW: Domestic hot water; DR: Demand response; DSM: Demand-side management; HP: Heat pump; ICT: Information and communications technology; KSH: Hungarian Central Statistical Office; LEADER: Liaison entre actions de développement de l'économie rurale; LEAP: The low emissions analysis platform; MEKH: Hungarian Energy and Utilities Regulatory Agency; PM: Particulate matter; SCOP: Seasonal coefficient of performance; SEE: Scenario standard energy efficiency; TES:

Thermal energy storage.

\section{Acknowledgements}

The authors would like to thank the two anonymous reviewers for their helpful comments and suggestions. Funding was provided by the Ökopolisz Foundation (Hungary) is gratefully acknowledged. The authors would like to thank Charles Heaps (Stockholm Environment Institute) and Ágnes Kelemen (Central European University) for contributing to the modeling work on the LEAP platform. Finally, the authors would like to thank all students involved in the field surveys.

\section{Authors' contributions}

JC and BM contributed to the conception and the design of the study. BM, CC, $\mathrm{AH}$, and $\mathrm{CG}$ designed the field surveys. CC was responsible for creating the database from the field surveys, data acquisition, and performing statistical analysis. ÁH analyzed biomass sources. GC analyzed spatial aspects of the area. JC was responsible for the modeling work on the LEAP software and writing the first draft of the manuscript. The scenarios were jointly elaborated between JC, BM, and CC. BM was the manager of the project. All authors contributed to manuscript revision and read and approved the submitted version.

\section{Funding}

The research presented in this article was funded by the Ökopolisz Foundation (Hungary).

\section{Availability of data and materials}

The datasets on population and housing stock analyzed during the current study are available in the Hungarian Central Statistical Office (KSH) repository [https://www.ksh.hu/housing]. Datasets on energy consumption are available from the Hungarian Energy and Public Utility Regulatory Authority (MEKH) repository [https://www.mekh.hu/home]. Links to specific datasets from these repositories are listed in the References section. The datasets generated from the field surveys during the current study are not publicly available.

Ethics approval and consent to participate

Not applicable.

Consent for publication

Not applicable.

Competing interests

The authors declare that they have no competing interests. 


\begin{abstract}
Author details
1 Department of Environmental and Landscape Geography, Eötvös Loránd University, Pázmány Péter sétány $1 / C, 1117$ Budapest, Hungary. ${ }^{2}$ WWF Hungary, Álmos vezér útja 69/A, 1141 Budapest, Hungary.
\end{abstract}

Received: 18 March 2020 Accepted: 20 October 2020 Published online: 30 November 2020

\section{References}

1. Guerreiro C, González Ortiz A, Leeuw F, Viana M, Colette A (eds) (2018) Air quality in Europe-2018 report. EEA, Louxembourg

2. Borsod-Abaúj-Zemplén Megye Környezetvédelmi Programja (2017-2022) https://www.baz.hu/content/cont_4948d5d9ccf1d4.02609709/1709.pdf. Accessed 5 Mar 2020

3. Ürge-Vorsatz D, Tirado Herrero S (2012) Building synergies between climate change mitigation and energy poverty alleviation. Energy Policy 49:83-90. https://doi.org/10.1016/j.enpol.2011.11.093

4. OECD (2019) Fossil fuel support country note-Hungary. https://stats .oecd.org/fileview2.aspx?IDFile=37348365-0442-4dd3-8d38-706eb3ad2d fa. Accessed 5 Mar 2020

5. MEKH (2018) Data of the Hungarian District Heating Sector (2017) https:// www.mekh.hu/download/fix/a_magyar_tavhoszektor_2017_evi_adatai. Accessed 5 Mar 2020

6. Smith KR, Nigel B, Balakrishnan K, Adair-Rohani H, Balmes J, Chafe Z, Dherani M, Hosgood D, Mehta S, Pope D, Rehfuess E (2014) Millions dead: how do we know and what does it mean? Methods used in the comparative risk assessment of household air pollution. Annu Rev Public Health 35:185-206. https://doi.org/10.1146/annurev-publhealth-03201 3-182356

7. Möller B, Wiechers E, Persson U, Grundahl L, Lund RS, Mathiese B (2019) Heat roadmap Europe: towards EU-wide, local heat supply strategies. Energy 177:554-564. https://doi.org/10.1016/j.energy.2019.04.098

8. Directive (EU) 2018/ of the European Parliament and of the Council of 30 May 2018 amending Directive 2010/31/EU on the energy performance of buildings and Directive 2012/27/EU on energy efficiency. https://eur-lex.europa.eu/legal-content/EN/TXT/?uri=urise rv\%3AOJ.L_.2018.156.01.0075.01.ENG. Accessed 5 Mar 2020

9. Persson U, Werner S (2011) Heat distribution and the future competitiveness of district heating. Appl Energy 88:568-576. https://doi. org/10.1016/j.apenergy.2010.09.020

10. Persson U, Möller B, Wiechers E (2017) Methodologies and assumptions used in the mapping. https://heatroadmap.eu/wp-content/uploa ds/2018/11/D2.3_Revised-version_180928.pdf. Accessed 5 Mar 2020

11. Boshell F, Veloza OP (2008) Review of developed demand side management programs, including different concepts and their results. In: 2008 IEEE/PES transmission and distribution conference and exposition: Latin America. IEEE, Bogota, Colombia, pp 1-7

12. Nyholm E, Puranik S, Mata É, Odenberger M, Johnsson F (2016) Demand response potential of electrical space heating in Swedish single-family dwellings. Build Environ 96:270-282. https://doi.org/10.1016/j.build env.2015.11.019

13. Papaefthymiou G, Haesen E, Sach T (2018) Power system flexibility tracker: indicators to track flexibility progress towards high-RES systems. Renew Energy 127:1026-1035. https://doi.org/10.1016/j.renene.2018.04.094

14. Gils HC (2014) Assessment of the theoretical demand response potential in Europe. Energy 67:1-18. https://doi.org/10.1016/j.energy.2014.02.019

15. Hashmi M (2011) Survey of smart grids concepts worldwide. VTT working papers 166. https://www.vtt.fi/inf/pdf/workingpapers/2011/W166.pdf. Accessed 05 Jul 2020

16. IRENA (2018) Power System Flexibility for the Energy Transition, Part 1 : Overview for policy makers, International Renewable Energy Agency, Abu Dhabi. https://www.irena.org/-/media/Files/IRENA/Agency/Publi cation/2018/Nov/IRENA_Power_system_flexibility_1_2018.pdf. Accessed 05 Jul 2020

17. Hedegaard K, Mathiesen BV, Lund H, Heiselberg P (2012) Wind power integration using individual heat pumps-analysis of different heat storage options. Energy 47:284-293. https://doi.org/10.1016/j.energ y.2012.09.030
18. Laicane I, Blumberga D, Blumberga A, Rosa M (2015) Reducing household electricity consumption through demand side management: the role of home appliance scheduling and peak load reduction. Energy Procedia 72:222-229. https://doi.org/10.1016/j.egypro.2015.06.032

19. Olkkonen V, Ekström J, Hast A, Syri S (2018) Utilising demand response in the future Finnish energy system with increased shares of baseload nuclear power and variable renewable energy. Energy 164:204-217. https ://doi.org/10.1016/j.energy.2018.08.210

20. Olkkonen $V$, Rinne S, Hast A, Syri S (2017) Benefits of DSM measures in the future Finnish energy system. Energy 137:729-738. https://doi. org/10.1016/j.energy.2017.05.186

21. Macedo MNQ, Galo JJM, Almeida LAL, Lima ACC (2015) Typification of load curves for DSM in Brazil for a smart grid environment. Int J Electr Power Energy Syst 67:216-221. https://doi.org/10.1016/j.jjepe s.2014.11.029

22. Sinha A, Neogi S, Lahiri RN, Chowdury S, Chakraborty N (2011) Role of demand side management for power distribution utility in India. In: 2011, IEEE Power and Energy Society General Meeting. IEEE, San Diego

23. Papaefthymiou G, Hasche B, Nabe C (2012) Potential of heat pumps for demand side management and wind power integration in the german electricity market. IEEE Trans Sustain Energy 3:636-642. https://doi. org/10.1109/TSTE.2012.2202132

24. Weitemeyer S, Kleinhans D, Vogt T, Agert C (2015) Integration of renewable energy sources in future power systems: the role of storage. Renew Energy 75:14-20. https://doi.org/10.1016/j.renene.2014.09.028

25. Gellings CW (2009) The smart grid: enabling energy efficiency and demand response. The Fairmont Press, Inc., Lilburn

26. Saele H, Grande OS (2011) Demand response from household customers: experiences from a pilot study in Norway. IEEE Trans Smart Grid 2:102-109. https://doi.org/10.1109/TSG.2010.2104165

27. Torriti J (2012) Demand side management for the European Supergrid: occupancy variances of European single-person households. Energy Policy 44:199-206. https://doi.org/10.1016/j.enpol.2012.01.039

28. Siemer L, Schöpfer F, Kleinhans D (2016) Cost-optimal operation of energy storage units: benefits of a problem-specific approach. J Energy Storage 6:11-21. https://doi.org/10.1016/j.est.2016.01.005

29. Imperial College London (2018) Analysis of alternative UK heat decarbonisation pathways. https://www.theccc.org.uk/publication/analysis-of-alter native-uk-heat-decarbonisation-pathways/. Accessed 5 Mar 2020

30. Grassi W (2017) Heat pumps: fundamentals and applications. Springer, Berlin

31. Panasonic (2019) New products 2019-2020 https://www.panasonicp roclub.com/uploads/HU/catalogues/EU\%20General\%20Catalogue\%20 19\%20Master\%20PSEE.pdf. Accessed 5 Mar 2020

32. Hesaraki A, Holmberg S, Haghighat F (2015) Seasonal thermal energy storage with heat pumps and low temperatures in building projects-a comparative review. Renew Sustain Energy Rev 43:1199-1213. https:// doi.org/10.1016/j.rser.2014.12.002

33. Arteconi A, Hewitt NJ, Polonara F (2013) Domestic demand-side management (DSM): role of heat pumps and thermal energy storage (TES) systems. Appl Therm Eng 51:155-165. https://doi.org/10.1016/j.applt hermaleng.2012.09.023

34. Hong J, Kelly NJ, Richardson I, Thomson M (2013) Assessing heat pumps as flexible load. Proc Inst Mech Eng Part A J Power Energy 227:30-42. https://doi.org/10.1177/0957650912454830

35. Schuetz P, Gwerder D, Gasser L, Fischer L, Wellig B, Worlitschek J (2017) Thermal storage improves flexibility of residential heating system for smart grids. In: 12th IEA Heat Pump Conference 2017, Rotterdam

36. IEA (2017) World Energy Outlook 2017-analysis. https://www.iea.org/ reports/worldenergy-outlook-2017. Accessed 5 Mar 2020

37. Söder L, Lund PD, Koduvere H, Bolkesjo TF, Rossebo GH, Rosenlund-Soysal E, Skytte K, Katz J, Blumberga D (2018) A review of demand side flexibility potential in Northern Europe. Renew Sustain Energy Rev 91:654-664. https://doi.org/10.1016/j.rser.2018.03.104

38. Rehman A, Deyuan Z (2018) Pakistan's energy scenario: a forecast of commercial energy consumption and supply from different sources through 2030. Energy Sustain Soc 8:26. https://doi.org/10.1186/s1370 5-018-0167-y

39. Xavier MVE, Bassi AM, de Souza CM, Filho WPB, Schleiss K, Nunes F (2013) Energy scenarios for the Minas Gerais State in Brazil: an 
integrated modeling exercise using system dynamics. Energy Sustain Soc 3:17. https://doi.org/10.1186/2192-0567-3-17

40. Stoeglehner G, Niemetz N, Kettl K-H (2011) Spatial dimensions of sustainable energy systems: new visions for integrated spatial and energy planning. Energy Sustain Soc 1:2. https://doi. org/10.1186/2192-0567-1-2

41. Ramirez Camargo L, Stoeglehner G (2018) Spatiotemporal modelling for integrated spatial and energy planning. Energy Sustain Soc 8:32. https://doi.org/10.1186/s13705-018-0174-z

42. LEAP (2020) The low emissions analysis platform. https://leap.sei.org/. Accessed 05 Jul 2020

43. KSH (2018) Statistical mirror (Statisztikai Tükör). Munkaerőpiaci folyamatok, 2018. I-III. negyedév. https://www.ksh.hu/docs/hun/xftp/idosz aki/mpf/mpf1809.pdf. Accessed 5 Mar 2020

44. The Carbon Trust (2014) User Guide 2.1 Manual, initial methodology report prepared by the Scottish Government. https://www2.gov.scot/ Resource/0048/00489200.pdf. Accessed 5 Mar 2020

45. Csoknyai T, Hrabovszky-Horváth S, Georgiev Z, Jovanovic-Popovic M, Stankovic B, Villatoro O, Szendrő G (2016) Building stock characteristics and energy performance of residential buildings in Eastern-European countries. Energy Build 132:39-52. https://doi.org/10.1016/j.enbui Id.2016.06.062

46. TIGAZ (2016) Calorific value tables (Fütőérték táblázatok). https://www. tigaz.hu//rendszerhasznaloknak/futoertek-tablazatok. Accessed 5 Mar 2020

47. Forest Research (2020) Moisture content. https://www.forestresearch. gov.uk/tools-and-resources/biomass-energy-resources/referencebiomass/facts-figures/moisture-content/. Accessed 5 Mar 2020

48. Mátrai Erőmú (2020) Coal sales (Bükkábrányi szénértékesítés). https:// www.mert.hu/hu. Accessed 3 Mar 2020

49. TABULA (2020) WebTool. https://webtool.building-typology.eu/\#bm. Accessed 5 Mar 2020

50. Harvey LDD (2013) Recent advances in sustainable buildings: review of the energy and cost performance of the state-of-the-art best practices from around the world. Annu Rev Environ Resour 38:281-309. https:// doi.org/10.1146/annurev-environ-070312-101940

51. Koliou E, Eid C, Chaves-Ávila JP, Hakvoort RA (2014) Demand response in liberalized electricity markets: analysis of aggregated load participation in the German balancing mechanism. Energy 71:245-254. https:// doi.org/10.1016/j.energy.2014.04.067

52. MAVIR (2018) Data of the Hungarian electricity system. https://erran et.org/wp-content/uploads/2016/11/Hungarian_Electricity_Syste m_2017.pdf. Accessed 5 Mar 2020

53. Prüggler N (2013) Economic potential of demand response at household level-are Central-European market conditions sufficient? Energy Policy 60:487-498. https://doi.org/10.1016/j.enpol.2013.04.044

54. Bernath C, Deac G, Sensfuß F (2019) Influence of heat pumps on renewable electricity integration: Germany in a European context. Energy Strategy Rev 26:100389. https://doi.org/10.1016/j. esr.2019.100389

55. Renaldi R, Kiprakis A, Friedrich D (2017) An optimisation framework for thermal energy storage integration in a residential heat pump heating system. Appl Energy 186:520-529. https://doi.org/10.1016/j.apene rgy.2016.02.067

56. KSH-Hungarian Central Statistical Office (2019) Time series of annual data_population, vital events. https://www.ksh.hu/stadat_annual_1. Accessed 3 Mar 2020

57. KSH-Hungarian Central Statistical Office (2019) Time series of annual data_housing and public utilities. https://www.ksh.hu/stadat_annua I_2_3. Accessed 3 Mar 2020

58. Cs C, Soha T, Harmat Á, Campos J, Csüllög G, Munkácsy B (2020) Spatial analysis of renewable-based rural district heating possibilities - a case study from Hungary. Int J Sustain Energy Plan Manag 28:17-36. https:// doi.org/10.5278/ijsepm.3661

59. Economidou M, Atanasiu B, Despret C, Maio J, Nolte I, Rapf O (2011) Europe's buildings under the microscope. A country-by-country review of the energy performance of buildings. Buildings Performance Institute Europe (BPIE)

60. Boeri A, Antonini E, Gaspari J, Longo D (2014) Energy design strategies for retrofitting: methodology, technologies and applications. WIT Press, Southampton
61. Shabbir R, Ahmad SS (2010) Monitoring urban transport air pollution and energy demand in Rawalpindi and Islamabad using leap model. Energy 35(5):2323-2332. https://doi.org/10.1016/j.energy.2010.02.025

62. Sadri A, Ardehali MM, Amirnekooei K (2014) General procedure for long-term energy-environmental planning for transportation sector of developing countries with limited data based on LEAP (long-range energy alternative planning) and EnergyPLAN. Energy 77:831-843. https ://doi.org/10.1016/j.energy.2014.09.067

63. Kusumadewi TV, Limmeechokchai B (2015) Energy efficiency improvement and $\mathrm{CO}_{2}$ mitigation in residential sector: comparison between Indonesia and Thailand. Energy Procedia 79:994-1000. https://doi. org/10.1016/j.egypro.2015.11.599

64. Subramanyam V, Kumar A, Talaei A, Mondal MAH (2017) Energy efficiency improvement opportunities and associated greenhouse gas abatement costs for the residential sector. Energy 118:795-807. https://doi. org/10.1016/j.energy.2016.10.115

65. DEFRA (2007) Guidelines to Defra's GHG conversion factors for company reporting. www.defra.gov.uk or www.carbonindependent.org/files/conve rsion-factors.pdf. Accessed 05 Jul 2020

66. DEFRA (2012) 2012 Guidelines to Defra / DECC's GHG Conversion factors for company reporting. https://www.gov.uk/government/uploads/syste m/uploads/attachment_data/file/69554/pb13773-ghg-conversion-. Accessed 05 Jul 2020

67. Moro A, Lonza L (2018) Electricity carbon intensity in European Member States: impacts on GHG emissions of electric vehicles. Transport Res Part D Transport Environ 64:5-14. https://doi.org/10.1016/j.trd.2017.07.012

68. EEA European Environment Agency (2016) EMEP/EEA Air Pollutant Emission Inventory Guidebook 2016: technical guidance to prepare national emission inventories. EEA-Report, 21. https://www.eea.europa.eu/publi cations/emep-eea-guidebook-2016. Accessed 05 Jul 2020

69. Kistler M, Schmidl C, Padouvas E, Giebl H, Lohninger J, Ellinger R (2012) Odor, gaseous and PM10 emissions from small scale combustion of wood types indigenous to Central Europe. Atmos Environ 51:86-93. https ://doi.org/10.1016/j.atmosenv.2012.01.044

70. DallO G, Galante A, Pasetti G (2012) A methodology for evaluating the potential energy savings of retrofitting residential building stocks. Sustain Cities Soc 4:12-21. https://doi.org/10.1016/j.scs.2012.01.004

71. Eurostat (2020) Natural gas price statistics. https://ec.europa.eu/eurostat/ statistics-explained/index.php?title=Natural_gas_price_statistics\&oldid $=336217$. Accessed 07 Jul 2020

72. Ferrari S, Zagarella F (2015) Costs assessment for building renovation cost-optimal analysis. Energy Procedia 78:2378-2384. https://doi. org/10.1016/j.egypro.2015.11.193

73. Panasonic (2020) New aquarea range 2019-2020 price list. https://www. panasonicproclub.com/uploads/IE/catalogues/IRE\%20A2W\%20PRI CE\%20LIST\%2019\%20LR.pdf. Accessed 05 Jul 2020

74. MEKH (2018) Household final energy consumption in Hungary (Háztartások végső energia felhasználása Magyarországon, felhasználási célok szerint). https://www.mekh.hu/download/f/b2/c0000/8_1_Haztartaso k_felhasznalasa_eves.xlsx. Accessed 5 Mar 2020

75. Österbring M, Camarasa C, Nägeli C, Thuvander L, Wallbaum H (2019) Prioritizing deep renovation for housing portfolios. Energy Build 202:109361. https://doi.org/10.1016/j.enbuild.2019.109361

76. Pikas E, Kurnitski J, Liias R, Thalfeldt M (2015) Quantification of economic benefits of renovation of apartment buildings as a basis for cost optimal 2030 energy efficiency strategies. Energy Build 86:151-160. https://doi. org/10.1016/j.enbuild.2014.10.004

77. Miara A, Tarr C, Spellman R, Vörösmarty CJ, Macknick JE (2014) The power of efficiency: optimizing environmental and social benefits through demand-side-management. Energy 76:502-512. https://doi. org/10.1016/j.energy.2014.08.047

78. Valero S, Ortiz M, Senabre C, Alvarez C, Franco FJG, Gabaldon A (2007) Methods for customer and demand response policies selection in new electricity markets. IET Gener Transm Distrib 1:104. https://doi. org/10.1049/iet-gtd:20060183

79. KSH - Hungarian Central Statistical Office (2019) Census (Népszámlálás 2011). Országos Adatok. https://www.ksh.hu/nepszamlalas/tablak_terul eti_00. Accessed 5 Mar 2020

80. Navarro-Espinosa A, Ochoa LF (2016) Probabilistic impact assessment of low carbon technologies in LV distribution systems. IEEE Trans Power Syst 31(3):2192-2203. https://doi.org/10.1109/tpwrs.2015.2448663 
81. Protopapadaki C, Saelens D (2017) Heat pump and PV impact on residential low-voltage distribution grids as a function of building and district properties. Appl Energy 192:268-281. https://doi.org/10.1016/j.apene rgy.2016.11.103

82. McKenna R, Djapic P, Weinand J, Fichtner W, Strbac G (2018) Assessing the implications of socioeconomic diversity for low carbon technology uptake in electrical distribution networks. Appl Energy 210:856-869. https://doi.org/10.1016/j.apenergy.2017.07.089

83. McKenna E, Thomson M (2014) Demand response behaviour of domestic consumers with photovoltaic systems in the UK: an exploratory analysis of an internet discussion forum. Energ Sustain Soc 4:13. https://doi. org/10.1186/2192-0567-4-13

84. Faruqui A, Harris D, Hledik R (2010) Unlocking the€ 53 billion savings from smart meters in the EU: how increasing the adoption of dynamic tariffs could make or break the EU's smart grid investment. Energy Policy 38(10):6222-6231. https://doi.org/10.2139/ssrn.1527165

85. Eid C, Codani P, Perez Y, Reneses J, Hakvoort R (2016) Managing electric flexibility from distributed energy resources: a review of incentives for market design. Renew Sustain Energy Rev 64:237-247. https://doi. org/10.1016/j.rser.2016.06.008
86. PVGIS (2020) Photovoltaic geographical information system. https://re.jrc. ec.europa.eu/pvg_tools/en/tools.htm|\#PVP. Accessed 5 Mar 2020

87. MEKH (2019) Report on distributed generation (Jelentés a negyedévente újonnan belépő háztartási méretű kiserőművekről 2018, Q4). https:// www.mekh.hu/download/8/28/a0000/jelentes_a_negyedevente_ujonn an_belepo_haztartasi_meretu_kiseromuvekrol_2018q4.pdf. Accessed 5 Mar 2020

88. KSH Hungarian Central Statistical Office (2020) Average net earnings (A teljes munkaidőben alkalmazásban állók kedvezmények nélküli nettó átlagkeresete a munkáltató székhelyének elhelyezkedése szerint). https:// www.ksh.hu/docs/hun/xstadat/xstadat_evkozi/e_qli030b.html. Accessed 5 Mar 2020

\section{Publisher's Note}

Springer Nature remains neutral with regard to jurisdictional claims in published maps and institutional affiliations.
Ready to submit your research? Choose BMC and benefit from:

- fast, convenient online submission

- thorough peer review by experienced researchers in your field

- rapid publication on acceptance

- support for research data, including large and complex data types

- gold Open Access which fosters wider collaboration and increased citations

- maximum visibility for your research: over $100 \mathrm{M}$ website views per year

At BMC, research is always in progress.

Learn more biomedcentral.com/submissions 